Ludanyi, Andrew. "Dani, Erzsébet. Identitásgyarmatositás Erdélyben: Identitásdrámák és interkulturális stratégiák a Trianon utáni székelymagyar irodalomban ('Identity Colonization in Transylvania: The Presence of Identity Narratives and Intercultural Strategies in the Literature of the Székely Magyars After Trianon'). Csíkszereda: ProPrint Publishers, 2016. 287 pp.." Hungarian Cultural Studies. e-Journal of the American Hungarian Educators Association, Volume 9 (2016): http://ahea.pitt.edu DOI: 10.5195/ahea.2016.238

\title{
Dani, Erzsébet. Identitásgyarmatosítás Erdélyben: Identitásdrámák és interkulturális stratégiák a Trianon utáni székelymagyar irodalomban ('Identity Colonization in Transylvania: The Presence of Identity Narratives and Intercultural Strategies in the Literature of the Székely Magyars After Trianon'). Csíkszereda: Pro-Print Publishers, 2016. 287 pp.
}

\author{
Reviewed by Andrew Ludanyi, Ohio Northern University
}

Erzsébet Dani's book Identitásgyarmatosítás Erdélyben ['Identity Colonization in Transylvania'] provides a new and original approach to understanding Romanian-Hungarian relations in the Easternmost part of Transylvania, the Székely region. This study is novel for a number of reasons: first, because it analyzes the fate of Transylvanian Hungarians mainly through the writings of Székely Hungarians of the interwar period; second, because it looks at the literary legacy in question not just from a historical and political perspective but also from a psycho-sociological and geo-cultural one; and thirdly, because Dani approaches the RomanianHungarian confrontation with admitted emotional involvement yet with a commitment to fairness and objectivity.

Before we look at the consequences of Dani's approach in the book's content, let me say a few things about the book's physical features. The book is made up of nineteen chapters, plus an extensive but selective bibliography (281-287). It is written in a reader-friendly direct style and effectively documented with eighty-four explanatory and source footnotes covering the works of its well chosen eight authors, whose photos appear on the cover of the book as if on a film-strip crossing the Transylvanian landscape. It is these larger than life individuals walking off the pages of Dani's book that come alive for us and enable us to better understand the complexity, pain and loss that are the consequences of trauma and aggressive assimilationist pressure in both the individual and group contexts.

Dani analyzes the writings of the following eight interwar Székely-Hungarian authors: Áron Tamási, Ferenc Balázs, Elek Benedek, György Bözödi, Rózsa Ignácz, Sándor Kacsó, Dezső László and József Nyírö. Except for Ignácz and Nyírő all of these writers focus on the Székely "island" settlement in the nook of the Eastern Carpathians and the Transylvanian Alps. Practically in the geographic center of present-day Romania, the Székelys constitute a solid block having a clear-cut eighty percent Hungarian majority among the ca. 700,000 inhabitants of this region. As opposed to this focus, Rózsa Ignácz's novels focus on the Csángo-Hungarians dispersed in Moldavia and residing in an overwhelmingly Romanian population; and the same can be said for the Hungarians of Mezőség, who populate József Nyírö's novels. In the first instance (the other six authors) we have a minority having a distinct majority in their region,

(cc) $\mathrm{Br}$

ULLS D-Serle 
Ludanyi, Andrew. "Dani, Erzsébet. Identitásgyarmatositás Erdélyben: Identitásdrámák és interkulturális stratégiák a Trianon utáni székelymagyar irodalomban ('Identity Colonization in Transylvania: The Presence of Identity Narratives and Intercultural Strategies in the Literature of the Székely Magyars After Trianon'). Csíkszereda: ProPrint Publishers, 2016. 287 pp.." Hungarian Cultural Studies. e-Journal of the American Hungarian Educators Association, Volume 9 (2016): http://ahea.pitt.edu DOI: 10.5195/ahea.2016.238

while the Csángos (in Ignácz's works) and the Hungarians of Mezőség (in Nyírő's works) are part of a minority population both regionally and within Romania as a whole.

The context of Dani's analysis is the "cultural trauma" suffered by the Hungarian population of the Erdély or Transylvania region following the dismemberment of historic Hungary in the 1920 Trianon Treaty. Yet Dani chooses not to linger on the trauma and instead focuses on its consequences because, as she notes, for the Székelys Trianon was initially less traumatic than for the rest of the region's Hungarians. Their status as a "compact island settlement," at least as far as their everyday lives were concerned, did not lead to drastic changes, or at least not immediately (37-38). However, their relative insulation was short-lived, as seen in the works of all the writers from Tamási to Nyírő. Unlike the Hungarians in the rest of Romania, the Székelys were geographically isolated within the Carpathian Basin, which enabled them to develop a unique "political culture" that was different not only from that of the Romanians and Saxon-Germans of the country but also from that of the Hungarians in general. This "kétkulacsos" (double-canteened) situation enabled the Székelys to "roll with the punches" in adverse historical circumstances as well as enabled them to maximize their independence from both central authorities and foreign foes or influences (34-35).

In the sixth chapter, in which Dani discusses theories of assimilation, she provides the backdrop for her analysis of the works of Transylvanian writers. This chapter analyzes the key models of the "ME" and "WE" identity formations in the context of "intercultural strategies" of the Székely "identity dramas." These theories and their discussion are supplemented by László Vetési's analysis of identity conceptions among the dwellers of scattered settlements beyond the Székely counties (50-52). Largely, these discussions present the Székelys as living within concentric circles of identity and loyalty leading from the furthest to the closest, starting with governmental political settings, going on to economic and employment relations, to educational and cultural institutions, and finally reaching religious and church affiliations. According to this theory, just as loyalty is further and further eroded in each of these circles of identity, so advances assimilation into the surrounding majority society.

According to Dani, Vetési's theory of the concentric circles of identity is supported by the insights of researchers of various fields and epochs, such as: László Gyurgyik, Rudolf Andorka, Milton M. Gordon, John M. Yinger, Brian Graham, G.J.Ashworth, Homi K. Bhabha, Anthony D. Smith, Everett M. Rogers, Thomas Erikson, Zoltán Bertha, György Csepeli, Nándor Bárdi and more. Dani succintly presents these scholars via their contribution to our understanding of the inner-group consciousness and of the assimilationist momentum sponsored by the dominant nationality. Among the issues discussed by Dani in the implemention of "border maintenance" the stages of integration into the majority culture may adhere to such models as the "tribal," the "melting pot," and the "salad dressing" or "rainbow" or "mosaic" models. Dani also reflects on the distinction between "indigeneous" or "historic peoples" as opposed to new migrant or immigrant peoples and their competition for living space and resources (57-58). Of no less importance in her analysis are the similarities she sees between colonialism and its aftermath and the colonizing momentum of the Romanian State.

What strategies and tactics can a besieged people adopt to face such colonizing powers? Which strategies and tactics can bring success in the preservation of identity and which lead to identity transformation and cultural absorption? In trying to answer these questions, Dani quotes 
Ludanyi, Andrew. "Dani, Erzsébet. Identitásgyarmatositás Erdélyben: Identitásdrámák és interkulturális stratégiák a Trianon utáni székelymagyar irodalomban ('Identity Colonization in Transylvania: The Presence of Identity Narratives and Intercultural Strategies in the Literature of the Székely Magyars After Trianon'). Csíkszereda: ProPrint Publishers, 2016. 287 pp.." Hungarian Cultural Studies. e-Journal of the American Hungarian Educators Association, Volume 9 (2016): http://ahea.pitt.edu DOI: 10.5195/ahea.2016.238

Norwegian anthropologist Thomas Erikson (b. 1962) who claims that states can relate to their minorities in three ways: "assimilate, oppress or segregate [them], or move in the direction of multi-culturalism" (61). In the different selections of literature discussed by Dani the minority's destiny is examined from the perspectives of these three approaches of the state toward its minorties, in this case the Székelys specifically.

Of all the literature examined by Dani, here I shall focus on two examples, one from Áron Tamási's work and one from József Nyírö's. In Tamási's case Dani presents his main character, Ábel, as the archtypical Székely. Ábel is nature's uncolonizable natural individual, who is able to assert himself even after the traumatic Trianon decision "when the Romanians became our handlers" (81). Ábel's encounters with others, including in his travels inside and outside Transylvania and during his stay in the United States, provide him with an understanding of the world and reaffirm his identity as a Székely-Hungarian. Ábel manages his "ME" identity in relation to the challenges he faces and the encounters he has with contractors purchasing lumber or outlaws and gendarmes in Romania as with bankers and mill and factory workers in the American setting. Thus Ábel demonstrates in his conduct that overcoming the Trianon trauma is possible by refusing to sink into an even deeper depression and, instead, by rising above the attempt to erase him from history through searching and finding practical solutions for his survival.

József Nyírő presents the challenges of post-1920 survival by portraying several individuals and their different responses to the colonization that moves forward in the Mezőség region. He portrays the figure of a guilt-ridden Baron who undermines the viability of a local Hungarian village by bringing in the cheap labor of Romanians to work his lands. To contrast this Baron, Nyírő creates the figure of the action-oriented János Fátyol, who fights against the poverty leading his community to extinction, and that of the daring Sándor Ösz, who steals the church bell to preserve at least a symbol of the Hungarian church for his community. Each of these characters exemplifies one or more response paths for minorities against the majority's assimilation efforts. This review cannot cover all of these minority responses in Nyírö's work. However, from the individualist stance of János Fátyol, to the "mimickri" of conformity, to the ultimate desperation-inspired escape via emigration, almost all options are explored by Nyíró's characters (137).

The most telling drama of the Székelys, though, is described by Áron Tamási's own personal encounter with representatives of the majority nationality in a train ride from Kolozsvár (Romanian Cluj Napoca) to his hometown Farkaslaka, in Udvarhely county. Tamási describes a scene in the staid first class section, in which four individuals including himself share one compartment and wherein the other three "naturally" assume that all four of them belong to the Romanian majority nation since only they can afford to travel first class. Soon, however, the national harmony of this majority is upset by the rustling of a Hungarian-written newspaper in the hands of Tamási, at which moment the staid unity of the majority freezes at the sight of this non-Romanian reading material in the safe haven of the majority's first class setting (126-129).

Through her analysis of Székely-Hungarian writers, Erzsébet Dani provides us with a study that is useful for all students of multi-ethnic and especially minority-majority relations; as such it would be an excellent addition to the reading material of any undergraduate or graduate course on East-Central Europe in the twentieth century. To serve this purpose, however, the book 
Ludanyi, Andrew. "Dani, Erzsébet. Identitásgyarmatositás Erdélyben: Identitásdrámák és interkulturális stratégiák a Trianon utáni székelymagyar irodalomban ('Identity Colonization in Transylvania: The Presence of Identity Narratives and Intercultural Strategies in the Literature of the Székely Magyars After Trianon'). Csíkszereda: ProPrint Publishers, 2016. 287 pp.." Hungarian Cultural Studies. e-Journal of the American Hungarian Educators Association, Volume 9 (2016): http://ahea.pitt.edu DOI: 10.5195/ahea.2016.238

should be translated into Romanian and all other neighboring languages as well as into English, German, French and Russian. It is also a study that Dani hopes could lead to dialogue between Romanians and Hungarians. In conclusion I would like to join Béla Pomogáts's postscript on the book's back cover and recommend it to all those who have an interest in East-Central Europe. Such studies open our eyes to the role of literature as not only reflecting the lives of oppressed groups and individuals but also as a vehicle for guiding oppressed communities in their everyday struggle for the preservation and expression of their identity. 